\title{
THE DEVELOPMENT OF FORESTRY IN ONTARIO
}

\author{
By E. J. ZAvitz, B.A., M.S.F., Provincial Forester of Ontario.
}

IN TREATING this subject it has been thought advisable to give you a brief picture of the policy pursued in connection with Ontario's forests from the time of British occupation.

When the British took possession in 1763 elaborate instructions were issued to Governor James Murray as to the administration of the forests. The British Government was particularly interested in reserving land for military and naval purposes and especially for the growth and production of naval timber. It is recorded that these instructions though subsequently repeated, were never seriously carried out.

At this time contractors were licensed by the Imperial Government to cut timber for the Royal Navy. These contractors took advantage of this privilege and carried on a general business with the British markets. These favored persons paid no revenue.

In 1826 the contractors monopoly was abrogated and for the first time a system of timber dues was inaugurated with a fixed scale of rates. A system allowing anyone to embark in the cutting of timber was established.

You may be interested to hear the description of one of these early timber limits. In 1836 a license was granted to James Wadsworth of Hull to cut Red Pine timber on an area described as follows: "Commencing one mile below Enoes Landing and to extend up on the south side of the river ten miles more or less to its source or so far as it is capable of floating down timber and to run back five miles, more or less, half way to the waters of the Madawaska River, on the course south 21 degrees west."

Up until 1840 the disposal of lands, timber and other resources was in the direct hands of the Crown. Abuse of these privileges, that is the giving out of lands and timber, was one of the causes of the rebellion of 1837 . After the rebellion Lord Durham was sent out to report on the causes of discontent. Following his report came the union of Upper and Lower Canada with a Government responsible to the people. One of the first things the new legislature took up was the administration of timber lands.

In 1842 new regulations as to the granting of licenses were adopted with the new element of sale by auction and a limited time for cutting.

In 1849 a select committee studied and reported on the timber trade and recommended certain changes in timber sales. In 1851 the new regulations provided for the imposition of "ground rent" in order to prevent the 
monopolization of unworked limits. By 1851 the system of disposing of Crown timber had become established in the form that it now exists in Ontario and Quebec.

New regulations in 1855 were of interest in that they affirmed the gov. ernment's right to charge ground rent and conditions of the license; in other words, the license conveyed no vested rights.

In 1859 we find in the Consolidated Statutes of Canada an "Act re, specting the sale and management of timber on Public Lands." This Act carried the more important elements to be found in the present Crown Timber Act.

After Confederation in 1867 timber administration in Ontario was car. ried on under the authority of the Consolidated Statutes of Canada 1859, Chap. 23. In 1877 with the consolidation of the Ontario Statutes there was passed an Act respecting the Sale and Management of Timber on Public Lands. This Act is R.S.O. 1877, Chap. 26.

We find that new Crown Timber Regulations were passed on the 16th April, 1869, superseding those of 1868. The Regulations of 1869 were established under authority of Chap. 23 of the Consolidated Statutes of Canada. It is interesting to note that the Regulations of 1869 remained practically unchanged until 1914, with the exception of Crown Dues and manufacturing clauses.

You will understand that previous to 1867 timber administration centered in Quebec, as the early exports of timber to Great Britain were shipped from that point.

The administration during this early period was in the hands of a Commissioner appointed by the Governor with Crown Timber Agents located at Ottawa, Montreal, Belleville, Toronto and various points in Quebec. It is interesting to note at this point that the supervisor of cullers was located in Quebec, and was appointed by the Mayor of Quebec City.

After Confederation in 1867 we find the administration of land and timber under the Department of Crown Lands, with a Commissioner, Assistant Commissioner and Superintendent of Woods and Forests. The Crown Timber Agents remained as outlined above.

Previous to Confederation very little record exists of public interest in the future of the forest. During the early 70's there began to develop public interest in Forestry, especially amongst agricultural leaders.

In 1871 we have the first Act to encourage planting of trees on highways with the idea of municipal assistance. 
In 1877 the Commissioner of Crown Lands, the Honourable T. B. Pardee, quotes in the Annual Report as follows:

"It is, of course, known that on the continent of Europe, where forests are in the hands of the Government, the cutting down of trees is rigidly regulated and restricted, a system of yearly planting being closely adhered to."

I will quote from the Report of the Fruit Growers' Association of Ontario for 1879_.

"The Fruit Growers Association needs to put forth their best efforts to husband our provincial and Dominion resources in their timber limitsto carefully instruct the farming community how much depends on the judicious planting of forest trees, their presence producing abundant rainfalls, preserving and distributing moisture and thereby forming a preventive against drought and devastating floods."

By 1879 an interest in forestry had developed in the minds of leading agriculturalists. That year the directors of the Ontario Fruit Growers Association decided to "take forestry under their fostering wing." This Association, which was composed of leading fruit growers from the various parts of older Ontario, played an important part in the discussion of forestry at their annual meetings over this period.

In the year 1879 William Brown who was in charge of the outside activities of the Agricultural College at Guelph was active in promulgating forestry ideas both at the College and through the agricultural meetings about this time. He was instrumental in making a number of small forest plantations at the Agricultural College at Guelph.

In 1881 the Agricultural and Arts Society awarded prizes for essays on forestry and these make rather interesting reading. A few of the prize essays may be found in the annual report of the Commissioner of Agriculture and Arts of Ontario for the year 1881. At this early date protection, land classification and reforestation were strongly advocated.

In 1881 the government appointed the Ontario Agricultural Commission to enquire into the conditions of agriculture. The forest in its relation to agriculture was made a subject of the enquiry. The findings are found in Chap. IV of the Ontario Agricultural Commission's report, 1881.

In 1882 the Ontario Government took enough interest in forestry to appoint three delegates to attend the American Forestry Congress held at Cincinnati, Ohio. William Saunders of London, D. W. Beadle of St. Catharines and William Brown of the Agricultural College, Guelph, at- 
tended this Congress. It is interesting to note that Bernard E. Fernow was a delegate at that Congress from a little town in Pennsylvania.

During the early 80's articles appeared in the Canada Farmer by a Mr. R. W. Phipps. From 1883 to $1891 \mathrm{Mr}$. Phipps, while not an official of the government, prepared reports for the government on forestry. These are contained in six reports published from 1883 to 1891. In this latter year he was appointed Clerk of Forestry. These reports give personal opinions and compiled articles on forestry.

In 1893 the government appointed a Royal Commission on forest reservation and national parks. This Commission was composed of Aubrey White, Assistant Commissioner, Crown Lands, Archibald Blue, Director of Mines, Alexander Kirkwood, Chief Clerk of the Lands Branch, and R. W. Phipps, with Thomas Gibson as Secretary.

Upon the recommendation of this Royal Commission, Algonquin Park was established in 1893 and Rondeau Park in 1894. It is interesting to note the reasons given for the creation of Algonquin Park, namely; 1. Maintenance of water supply; 2. Preservation of a primeval forest; 3 . Protection of birds and animals; 4. A field for experiments in forestry; 5. A place of health resort; 6. Beneficial effects on climate. (Sze Report of Commission on Forest Reservation and National Park, 1893.)

In 1895 Thomas Southworth was appointed as Clerk of Forestry and held that office until 1902. His report covering this period contained many articles on forestry and recommendations regarding various matters connected therewith. At that time the Clerk of Forestry had no administrative connection with the administration of the Crown Timber Act.

In 1897 a Royal Commission on Forestry in Ontario was created with Thomas Southworth as Secretary. Instructions to the Commission were "To investigate and report on the subject of restoring and preserving the growth of white pine and other timber trees upon land in the Province which are not adapted for agricultural purposes or for settlement." This Commission was composed of a number of prominent lumbermen of the day, and their findings are recorded in the report of 1898.99. Through the findings of this Commission the Forest Reserves Act was passed in 1898 , and in that same year two forest reserves were created, namely, the Eastern Forest Reserve in Eastern Ontario and the Sibley Forest Reserve on the north shore of Lake Superior. The main value of the above Act was the prevention of settlement taking place within these areas. It is interesting to note that the report recommended improvements in fire ranging 
system; a twelve-inch diameter limit in cutting and the setting aside of Crown forest reserves.

$\mathrm{Up}_{\mathrm{p}}$ to 1900 no Canadian foresters, technically trained, had appeared on the horizon. However, about this time three graduates of the Ontario Agricultural College at Guelph had gone to the United States to study forestry. Norman Ross was at Biltmore and was appointed to Ottawa in 1902 in connection with the production and distribution of trees for the western provinces. R. D. Craig, a graduate of Cornell in 1902, was for a time attached to the U.S. Forest Service, after which he was appointed to the Department of Interior in 1904. Dr. Judson F. Clarke, Cornell, 1902, was on the staff of Cornell for some time, and then with the U.S. Forest Service. He was appointed as Provincial Forester of Ontario in August, 1904.

About 1902 a Forestry Committze was appointed in connection with the Ontario Agricultural Experimental Union, which held its meetings at the Agricultural College at Guelph. This Committee recommended, amongst other things, the establishment of a School of Forestry, reforestation of waste lands, woodlot improvement and exemption from taxation on woodlands.

At this time there was considerable pressure from three sources to secure the School of Forestry. Queens University held a conference on forestry education in January, 1901. Later, in 1903, Dr. Fernow delivered a series of ten lectures at Queens. In November, 1902, the Senate of the University of Toronto adopted a curriculum in forestry. Plans were already under way to provide for a Forestry School at the Ontario Agricultural College.

In 1906 a Royal Commission on education for Ontario reported on the need of a Forestry Department in connection with the University of To. ronto and recommended the same. This School was established in 1907 under Dr. Fernow as Dean.

Largely through the recommendations of the Experimental Union at Guelph the Provincial Government voted money to establish a nursery at the Ontario Agricultural College in 1904. The writer was temporarily appointed in charge of this work during the summer of 1904. At this time Dr. J. F. Clarke was appointed Provincial Forester at Toronto in an advisory capacity and had no administrative duties. He remained in this position for a few months and retired to private practice.

In 1905 the writer was appointed lecturer and forester at the Ontario Agricultural College. A nursery was established at the College and lectures. 
were given to students and extension work was done amongst farmers. The nursery at Guelph from 1905 to 1908 provided planting material for a number of experimental plantings throughout the Province on private land. owners' properties.

In 1908 a report was made by the writer on the waste land areas of older Ontario, and in that year the Government decided to establish a forest station in Norfolk County upon one of these areas. Owing to lack of suitable land, the forest nurseries were moved from the Agricultural College to this new station in Norfolk County. This station started with 100 acres of land and gradually increased its holdings to the present acreage of 3,800 .

This station contains nurseries and experimental plantations together with a number of natural woodlands under management.

In 1911 the Counties Reforestation Act was passed, but no direct results obtained until a few years later.

In 1912 the writer was appointed Director of Forestry and the headquarters of the work in Southern Ontario was moved to Toronto, and the work was transferred from the Department of Agriculture to the Department of Lands and Forests.

In 1913 F. S. Newman was appointed Assistant Director and placed in charge of the Provincial Forest Station in Norfolk.

Up to this date the Forestry Branch was simply concerned with reforestation and forest problems in Southern Ontario, with no administrative relation to the problems of timber administration.

In 1917 The Forest Fires Prevention Act was passed and forest protection was placed under the Provincial Forester. Up to 1917 no permanent field organization had been provided to handle this problem. At this time Dr. J. H. White was appointed as Assistant Provincial Forester and acted in this capacity until 1919. Three field superintendents were appointed and an attempt was made to develop a permanent field staff.

During 1920 a reconnaisance survey was made of the Ottawa-Huron region and three districts were established in 1921, namely, Algonquin, Georgian Bay and Tweed with forestry graduates as district foresters in charge, being respectively W. A. Delahey, P. McEwen and G. M. Dallyn.

In 1921 two additional foresters were appointed to Head Office, namely, C. R. Mills as Assistant Provincial Forester and A. H. Richardson as Forester in Charge of Reforestation. 
Under the authority of The Forestry Act, 1927, a Forestry Board of five members was appointed for the purpose of carrying on research work in connection with the forestry lands of the Province of Ontario. This Board consisted of three members of the forest industries and two from the Ontario government forest service. Several meetings were held when certain recommendations were made to the Administration.

By 1930 the Province had been divided into 12 districts with graduate foresters in charge of forest protection and other technical problems. As yet the timber administration was separate and had changed very little throughout the years.

During the period 1920-1930 systematic forest surveys were carried on, the results of which were embodied in the report "Forest Resources of Ontario" by Sharpe and Brodie, this being the first authentic summary of the forest resources of the Province.

During this period also-namely, from 1920 on-there was renewed interest in reforestation. In 1922, two new nurseries were commenced, one at Orono in Durham County, the other at Midhurst in Simcoe County.

In 1924, the first year in which these two nurseries commenced to distributz trees to any extent, the total output of all three nurseries was around one million trees. This has steadily increased until this year, 1939, the stock available for distribution is $22,000,000$.

In 1922 the Counties Reforestation Act of 1911 was resurrected and the County of Simcoe purchased 1,000 acres of waste land and commenced the first county forest. Simcoe still leads in this work and at present has-a total of 4,500 acres being managed under this scheme. Other counties soon took advantage of the Department's offer so that now there are sixteen of these forests in operation owned by twelve different counties with a total acreage of 18,227 . In addition to the county forests mentioned there are also 85 smaller municipal forests ranging from a few acres to 100 in size and 300 private demonstration woodlots.

In 1920 the Provincial Seed Extracting Plant began to operate at Angus, Ontario. Prior to this time the quantity of seed used was quite small and was either gathered locally at St. Williams or, in the case of exotic species, purchased abroad. With the expanding of the reforestation work a large quantity of native seed became necessary and the headquarters for this work, with up-to-date extracting and cleaning methods, was established at Angus, in Simcoe County. 
In 1926 reforestation work on Crown land in Northern Ontario was commenced. Some of this has been done by direct seeding, most of it by planting. The total area of such work to date is 8,263 acres.

The distribution of trees for planting waste land, supplementing farm woodlots and the establishing of windbreaks on agricultural land has always been of primary importance in the work. In 1920 the number of persons procuring such material was a few hundred; in 1938 the number had reached 8,000 .

In 1934 a very important development took place when, through a re-organization of the Department of Lands and Forests, all forest activities were combined under the various district forest offices. 